\title{
Distres Psikologis di Masa Pandemi COVID 19: Sebuah Tinjauan Literatur Sistematis
}

\author{
GUSTI AYU ARDHIA CANDRA TRIKUSUMA* \& WIWIN HENDRIANI \\ Fakultas Psikologi, Universitas Airlangga
}

\begin{abstract}
ABSTRAK
Pandemi Coronavirus Disease-19 (COVID-19) menimbulkan distres psikologis bagi masyarakat yang terdampak sehingga dibutuhkan adanya kesadaran terkait seperti apa distres psikologis yang ditimbulkan di masa pandemi. Studi ini merupakan tinjauan literatur dengan pendekatan sistematis yang bertujuan untuk menggali tentang ragam distres psikologis yang muncul pada masyarakat terdampak pandemi COVID-19, gejala-gejala yang ditimbulkan, serta mengenali apa saja stressor yang menimbulkan gejala-gejala tersebut. Adapun hasil dari studi ini yaitu distres psikologis yang dominan dirasakan masyarakat terdampak COVID-19 meliputi gejala kecemasan, gejala depresi, gejala stres akut, serta gejala post-traumatic stress disorder (PTSD). Gejala-gejala distres psikologis lainnya yang dirasakan berupa perasaan kesepian, ketidakberdayaan, kemarahan, ketakutan, insomnia, penghindaran stressor, mimpi buruk, pusing, serta palpitasi. Penyebab kemunculan gejala tersebut dipicu oleh adanya stressor berupa kondisi ketidakpastian, hilangnya sense of control, ketidakberdayaan, persepsi negatif terkait kesehatan orang lain, tinggal sendirian saat menjalani karantina, tingginya risiko individu terpapar COVID-19, dekatnya jarak dengan orang yang berisiko tinggi atau penderita COVID19 , serta adanya stigmatisasi dari orang sekitar.
\end{abstract}

Kata kunci: distres, depresi, kecemasan, stigma, stressor

\begin{abstract}
The Coronavirus Disease-19 (COVID-19) pandemic causes psychological distress for people affected so that awareness is needed regarding what kind of psychological distress is caused during the pandemic. This study is a literature review with a systematic approach that aims to explore the variety of psychological distress that appears in communities affected by the COVID-19 pandemic, the symptoms caused, and identify what stressors are causing these symptoms. The results of this study are psychological distress that is dominantly felt by people affected by COVID-19 including symptoms of anxiety, symptoms of depression, symptoms of acute stress, and symptoms of post-traumatic stress disorder (PTSD). Other symptoms of psychological distress are feelings of loneliness, helplessness, anger, fear, insomnia, stressor avoidance, nightmares, dizziness, and palpitations. The cause of the emergence of these symptoms is triggered by stressors in the form of conditions of uncertainty, loss of sense of control, helplessness, negative perceptions related to the health of others, living alone while undergoing quarantine, high risk of individuals being exposed to COVID-19, proximity to high-risk people or COVID-19 sufferers as well as the stigmatization of the people around them.
\end{abstract}

Keywords: anxiety, depression, distress, stigma, stressor 
INSAN Jurnal Psikologi dan Kesehatan Mental, 2021, Vol. 6(2), 106-116, doi: 10.20473/jpkm.v6i22021.106-116 Dikirimkan: 8 Oktober 2021 Diterima: 28 November 2021 Diterbitkan: 1 Desember 2021

Editor: Rizqy Amelia Zein

*Alamat korespondensi: Fakultas Psikologi Universitas Airlangga, Kampus B Universitas Airlangga Jalan Airlangga 4-6 Surabaya 60286. Pos-el: gusti.ayu.ardhia-2020@psikologi.unair.ac.id

Naskah ini merupakan naskah dengan akses terbuka dibawah ketentuan the Creative Common Attribution License (http://creativecommons.org/licenses/by/4.0), sehingga penggunaan, distribusi, reproduksi dalam media apapun atas artikel ini tidak dibatasi, selama sumber aslinya disitir dengan baik.

\section{P E N D A H U L U A N}

Coronavirus Disease-19 (COVID-19) merupakan penyakit infeksi saluran pernapasan yang disebabkan oleh virus SARS-CoV-2. Awalnya, persebaran COVID-19 dimulai di Kota Wuhan, China, namun hingga kini persebarannya telah terjadi secara global, termasuk di Indonesia. Akibat persebaran COVID-19 yang begitu masif dalam waktu singkat, pada Maret 2020, World Health Organization (WHO) mengumumkan secara resmi wabah COVID-19 sebagai pandemi global (WHO, 2020). Dong dan Buoey (2020) menjelaskan bahwa perbedaan wabah COVID-19 dibanding penyakit lain dengan karakteristik virus yang sama yaitu; transmisinya terbilang sangat cepat, banyaknya kasus-kasus tanpa gejala (asymptomatic) yang memicu ketakutan dan kecemasan, kurangnya transparansi pemerintah terkait data kasus, kurangnya kompetensi pemerintah dalam hal pengambilan keputusan terkait kondisi pandemi COVID-19, adanya pembatasan sosial skala besar atau pembatasan aktivitas masyarakat di luar rumah sehingga berpotensi menimbulkan dampak negatif dari segi psikologis, terbatasnya fasilitas dan tenaga kesehatan, serta adanya karakteristik infodemic atau maraknya informasi yang salah mengenai COVID-19 di media sosial sehingga dapat mengancam kesehatan mental masyarakat.

Di Indonesia, kasus COVID-19 telah tersebar di semua provinsi secara masif, dan setiap harinya ribuan kasus positif terus bertambah. Pemerintah Indonesia telah melaksanakan berbagai upaya pencegahan penyebaran COVID-19 melalui kebijakan pembatasan sosial berskala besar (PSBB) yang diterapkan di lingkungan masyarakat, dengan harapan pemberlakuan pembatasan jarak sosial akan menurunkan angka penyebaran penyakit COVID-19 (Mashabi, 2020). Namun, di sisi lain hal tersebut juga menimbulkan kondisi mengkhawatirkan bagi berbagai aspek kehidupan masyarakat di bidang lainnya, seperti di bidang ekonomi, kualitas penanganan masalah kesehatan, masalah pendidikan, dan yang paling disoroti yaitu adanya indikasi meningkatnya masalah psikologis akibat pandemi COVID-19.

Survei yang dilakukan secara daring oleh Perhimpunan Dokter Spesialis Kedokteran Jiwa Indonesia (PDSKJI) yang dilakukan di 34 provinsi di Indonesia menemukan bahwa sebanyak 63 persen responden mengalami cemas dan 66 persen responden mengalami depresi akibat pandemi COVID-19. Gejala cemas yang dirasakan adalah merasa khawatir sesuatu yang buruk akan terjadi, khawatir berlebihan, mudah marah dan sulit rileks, sedangkan gejala depresi yang muncul adalah gangguan tidur, kurang percaya diri, lelah, tidak bertenaga dan kehilangan minat. Sebanyak 80 persen responden memiliki gejala stres pasca trauma psikologis karena mengalami atau menyaksikan peristiwa tidak menyenangkan akibat COVID-19. Sebanyak 46 persen responden mengalami gejala stres pasca trauma berat, 33 persen responden mengalami gejala stres pasca trauma sedang, dan 2 persen responden mengalami gejala stres pasca trauma ringan (Perhimpunan Dokter Spesialis Kesehatan Jiwa Indonesia, 2020). WHO (2020)

INSAN Jurnal Psikologi dan Kesehatan Mental 2021, Vol. 6(2), 106-116

doi: 10.20473/jpkm.v6i22021.106-116

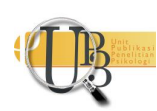


menjelaskan bahwa dalam aspek kesehatan mental, pandemi COVID-19 menyebabkan peningkatan stres dan kecemasan pada masyarakat.

Centers for Disease Control and Prevention (CDC) (2020) mengungkapkan bahwa stres berlebih yang dialami individu saat masa pandemi COVID-19 dapat menyebabkan rasa takut dan kekhawatiran berlebih terkait kondisi kesehatan keluarga atau orang terdekat, perubahan pola tidur dan pola makan, sulit tidur yang berujung sulitnya berkonsentrasi, memperburuk masalah kesehatan fisik dan mental, serta peningkatan konsumsi rokok dan obat-obatan terlarang. Selain itu, adanya karantina berpotensi meningkatkan kecenderungan masyarakat merasakan kesepian dan kebosanan, menggunakan alkohol dan obat-obatan terlarang, bahkan dapat berujung pada self-harm dan tindak bunuh diri. Thakur dan Jain (2020), menyatakan bahwa empat dari 14 faktor risiko utama depresi setidaknya muncul akibat pandemi COVID-19, yaitu isolasi, tekanan ekonomi, stres dan depresi pada tenaga kesehatan dan stigma dan diskriminasi.

Sarafino dan Smith (2014) mendefinisikan stres sebagai adanya persepsi tuntutan dari berbagai aspek internal maupun eksternal individu sebagai dampak adanya interaksi antara lingkungan dengan individu itu sendiri. Segala tuntutan dan peristiwa tersebut kemudian dinilai membebani atau bahkan melebihi batas daya adaptif individu, sehingga akan menimbulkan tekanan psikologis (Folkman \& Lazarus, 1985). Respon individu terhadap situasi menuntut atau mengancam dapat berupa respon fisik dan psikologis (Sarafino \& Smith, 2014). Respon fisik umumnya berupa sakit kepala, gangguan tidur, gangguan pencernaan, gangguan pernafasan, serta detak jantung tidak beraturan. Respon psikologis dapat dibagi menjadi tiga yaitu; aspek kognisi, umumnya berupa gangguan daya ingat dan daya konsentrasi; aspek emosi, yaitu berupa perasaan sedih, bosan, marah, depresi, cemas, gelisah, dan mudah marah; dan aspek perilaku yang umunya berupa sulit bekerja sama, kehilangan minat, tidak mampu rileks, memunculkan perilaku bermusuhan, serta meningkatnya konsumsi alkohol dan obatobatan terlarang.

Kurva Yerkes-Dodson tentang stres terhadap performa mengilustrasikan bahwa stres bersifat menguntungkan pada titik fungsi optimal (plateau) yaitu pada titik tengah kurva, yang mana di atas titik tersebut seiring dengan meningkatnya stres, maka akan terjadi penurunan performa (Katona, Cooper, \& Robertson, 2012). Hal ini menunjukkan adanya perbedaan dampak dari stres tergantung pada intensitasnya. Stres yang terjadi pada individu dapat dikategorikan menjadi eustres dan distress. Eustress adalah stres yang memberikan dampak positif, sedangkan distress adalah stres yang memberikan dampak negatif (Gadzella, Baloglu, Masten, \& Wang, 2012). Menurut Mirowsky dan Ross (2003), dua bentuk utama distres psikologis berupa gejala kecemasan dan gejala depresi.

Semakin maraknya kasus terkonfimasi positif COVID-19 di Indonesia menyebabkan semakin membuat masyarakat mudah merasa cemas dan takut akan pandemi tersebut. Menurut Taylor (2019), gejala kecemasan dan rasa takut menjadi lebih lazim ketika pandemi melanda masyarakat. Gejala kecemasan dan rasa takut dengan level sedang dapat memotivasi seseorang untuk berusaha coping sedangkan kecemasan dan rasa takut yang berlebihan dapat melemahkan seseorang. Pada masa pandemi severe acute respiratory syndrome (SARS), banyak pasien SARS mengalami distres psikologis, termasuk gejala stres pascatrauma (post-traumatic stress disorder - PTSD), yang tetap muncul meskipun pasien telah sembuh dari penyakit tersebut. Bahkan di beberapa kasus, pasien tetap mengalami gejala tersebut meski telah sembuh dari efek fisik dari penyakit SARS. Penyebab penyakit SARS menimbulkan stres adalah; 1) penyakit SARS merupakan penyakit infeksi baru yang belum diketahui cara penanganannya; 2) infeksi dikendalikan dengan melakukan isolasi; dan 3) adanya ketakutan penyebaran penyakit yang 
kurang diketahui ini kepada orang lain (Taylor, 2019). Hal yang sama juga dialami masyarakat saat pandemi COVID-19 melanda Indonesia sehingga menimbulkan distres psikologis pada masyarakat.

Kecemasan dan rasa takut yang dirasakan dapat menjadi distres yang membuat masyarakat semakin rentan terkena penyakit kesehatan mental seperti depresi. Tanpa masyarakat sadari, beberapa gejala kecemasan dan depresi telah mereka alami akibat pandemi dan tidak mendapatkan penangangan yang tepat sehingga dapat memengaruhi kehidupan mereka. Selain kecemasan dan rasa takut akibat pandemi COVID-19, faktor lain yang dapat menyebabkan distres psikologis pada individu adalah kondisi ekonomi yang semakin memburuk ditandai dengan banyak ancaman pemutusan hubungan kerja (PHK) bagi para karyawan dan pemberlakuan metode belajar daring sehingga para siswa yang masih bersekolah tidak dapat berinteraksi dengan teman-teman sebayanya. Hasil survei yang dilakukan oleh PDSKJI menunjukkan masalah psikologis terbanyak ditemukan pada individu dengan kelompok usia 17-29 tahun dan usia diatas 60 tahun. Dari total 4010 swaperiksa yang dilakukan oleh PDSKJI, terdapat 1725 swaperiksa depresi dan 62 persen diantaranya dengan masalah psikologis depresi dan 44 persen dari mereka berpikir lebih baik mati atau ingin melukai diri sendiri dengan cara apapun. Dari survei tersebut, pikiran kematian banyak muncul pada usia 18-29 tahun (Perhimpunan Dokter Spesialis Kesehatan Jiwa Indonesia, 2020).

Hal tersebut menunjukkan adanya dampak yang merugikan bagi masyarakat maupun orang sekitar akibat distres akibat pandemi COVID-19 menunjukkan pentingnya pemahaman terhadap ragam distres psikologis utamanya terkait masa pandemi COVID-19 serta gejala-gejala yang mungkin ditimbulkan, sehingga dapat dilakukan langkah preventif terhadap dampak negatif tersebut. Berdasarkan uraian di atas, maka tujuan dalam studi ini yaitu untuk mengetahui distres psikologis selama masa pandemi COVID-19 beserta gejala yang ditimbulkan dan stressor atau penyebab kemunculan gejala tersebut, sehingga masyarakat dapat antisipatif dalam menghadapi stressor di masa pandemi serta mampu mengambil langkah preventif terhadap kemunculan distres psikologis yang dialami agar tidak berkembang ke arah gangguan psikologis.

\section{E T O D E}

Studi ini merupakan tinjauan literatur dengan pendekatan sistematik. Tinjauan literatur ini berfokus untuk menyediakan informasi mengenai dampak psikologis masa pandemi COVID-19 pada masyarakat, bentuk-bentuk distres yang dialami, serta stressor yang memicu kemunculan distres tersebut. Pencarian artikel penelitian dilaksanakan pada Oktober 2020 untuk menyortir artikel yang dipublikasikan antara tahun 2019-2020 mengingat kemunculan COVID-19 yaitu pada Desember 2019 di Kota Wuhan, China. Artikel-artikel penelitian yang telah disortir kemudian diunduh untuk mempermudah peninjauan secara menyeluruh sehingga dapat diperoleh informasi yang komprehensif mengenai dampak psikologis masa pandemi COVID-19.

Adapun basis data yang digunakan dalam studi ini yaitu, ScienceDirect, dan beberapa artikel penunjang yang diperoleh dari Pubmed, serta Google Scholar. Artikel-artikel yang telah disaring melalui kombinasi dan penambahan kata kunci kemudian disaring kembali secara manual dengan membaca masingmasing abstrak dalam artikel tersebut untuk menemukan artikel yang memang relevan dengan tujuan dalam studi ini. 


\section{Strategi pencarian}

Artikel yang digunakan dalam tinjauan literatur ini meliputi ; (1) artikel yang dihasilkan dari pencarian dengan kata kunci "psychological", "impact", dan "COVID 19", (2) artikel yang dihasilkan dari pencarian dengan kata kunci "psychological", "impact", "COVID 19", dan "adult", (3) artikel yang dihasilkan dari pencarian dengan kata kunci "psychological", "impact", "COVID 19", "adult", dan "stress", (4) artikel yang dihasilkan dari pencarian dengan kata kunci "psychological", "impact", "COVID 19", "adult", dan "patient", (5) artikel yang digunakan merupakan artikel penelitian dengan metode kualitatif dan/atau metode kuantitatif.

Artikel yang tidak digunakan dalam tinjauan literatur ini yaitu; (1) studi yang merupakan tinjauan pustaka atau ulasan mengenai penelitian yang telah dilakukan sebelumnya, (2) penelitian dengan partisipan anak-anak atau remaja, (3) penelitian dengan subjek yang merupakan tenaga kesehatan. Strategi pencarian dan pemilahan literatur dijabarkan dalam diagram alir pada Gambar 1.

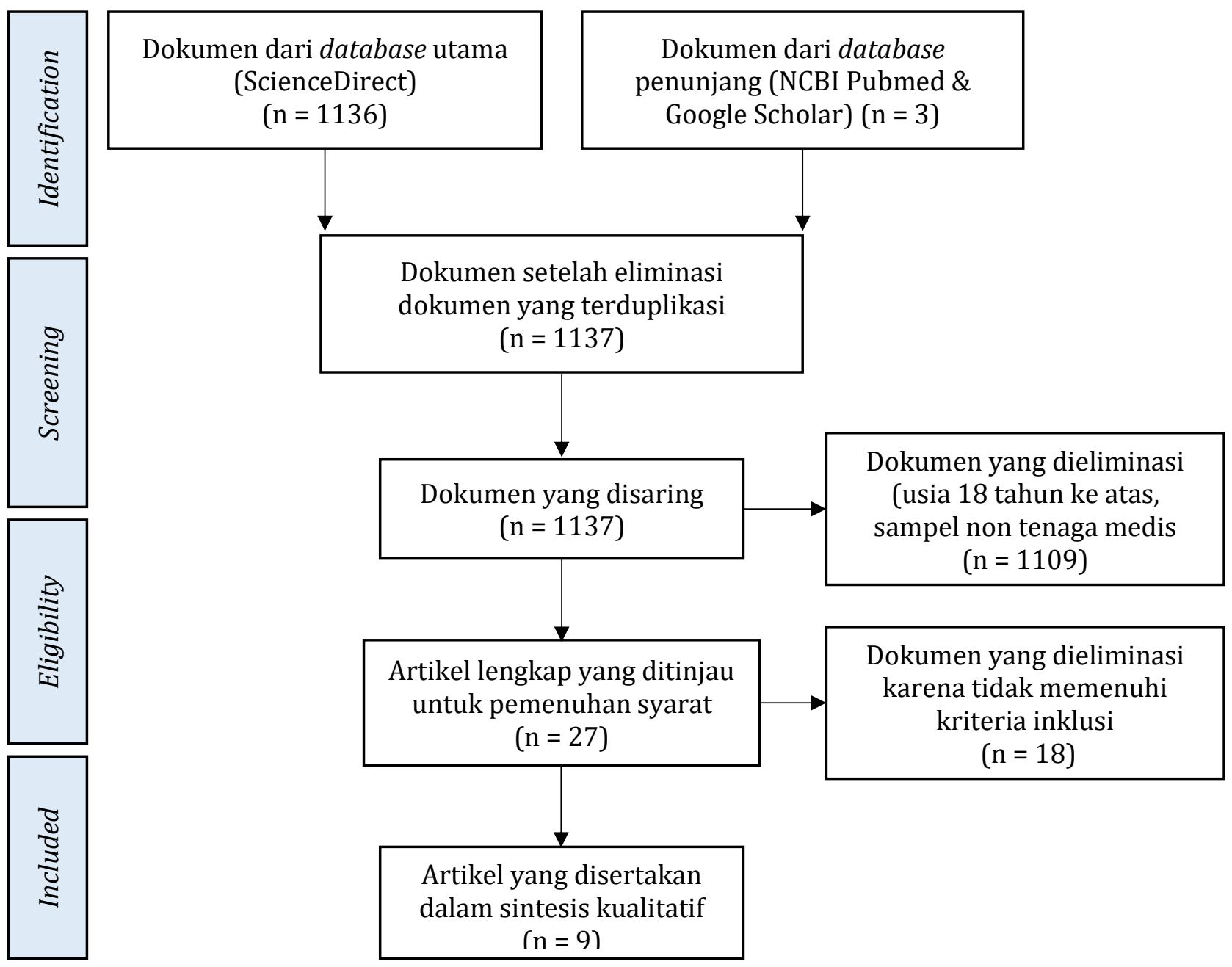

Gambar 1. Diagram Alir Pencarian dan Seleksi Artikel 


\section{HAS IL P E N ELIT IAN}

Berdasarkan hasil pencarian akhir artikel yang akan ditinjau, diperoleh sembilan artikel yang dinilai memenuhi kriteria inklusi dan eksklusi, serta relevan dengan topik studi ini yaitu distres psikologis pada masa pandemi COVID-19. Secara umum artikel-artikel yang ditinjau dalam studi ini mengambil sampel penelitian yang meliputi individu yang merupakan pasien COVID-19 (pasien rawat inap di rumah sakit maupun rawat jalan atau yang menjalani isolasi mandiri atau penyintas COVID-19) serta individu yang tidak menderita COVID-19 namun menjalani karantina selama masa pandemi COVID-19. Sembilan artikel dalam penelitian ini memuat informasi mengenai prevalensi distres psikologis yang dialami masyarakat selama masa pandemi COVID-19, bentuk atau gejala distres yang dialami, stressor atau penyebab munculnya stres, serta faktor-faktor yang mempengaruhi.

\section{Distres psikologis pada non-pasien atau penyintas COVID-19}

Individu dengan gangguan kecemasan memiliki angka lebih tinggi terkait skor total COVID Stress Scale serta skor yang lebih tinggi terkait ketakutan akan kontaminasi, konsekuensi sosio-ekonomi, xenophobia, serta gejala PTSD dibanding kelompok lainnya. Individu dengan gangguan mood memiliki angka yang lebih tinggi terkait gejala PTSD dan konsekuensi sosio-ekonomi dibanding kelompok yang tidak memiliki gangguan psikologis (Asmundson, dkk., 2020). Pada penelitian yang dilakukan oleh Lahav (2020) dengan melibatkan 976 partisipan yang mana 793 di antaranya pernah mengalami traumatic event, serta 255 lainnya mengalami continuous traumatic stress, stressor yang dilaporkan partisipan selama masa pandemi COVID-19 yaitu karantina, hidup sendiri di masa pandemi, berada di kelompok yang berisiko tinggi tertular COVID-19, persepsi negatif mengenai kesehatan fisik orang sekitar, berada di dekat penderita COVID-19, serta berada di dekat orang yang berisiko tinggi tertular COVID-19. Distres psikologis yang dialami sebagian partisipan yaitu setidaknya satu kriteria gangguan kecemasan, gangguan depresi, serta PTSD. Sedangkan pada penelitian yang dilakukan oleh Shi, dkk. (2020) menunjukkan sekitar 24,4 persen hingga 31,6 persen partisipan menunjukkan adanya gejala depresi, kecemasan, insomnia, serta stres akut. Populasi yang rawan mengalami masalah psikologis akibat pandemi COVID-19 yaitu individu yang positif maupun masih yang dicurigai menderita COVID19, individu dengan pekerjaan yang berisiko tinggi terpapar COVID-19, individu yang menjalankan karantina, individu yang tinggal di Provinsi Hubei, dan yang belum bisa pulang karena urusan pekerjaan.

\section{Distrss psikologis pada pasien atau penyintas COVID-19}

Penelitian yang dilakukan oleh Parker, dkk. (2020) menunjukkan bahwa prevalensi kemunculan gejala depresi dan kecemasan tinggi pada pasien COVID-19 yang dirawat di rumah sakit. Sebanyak 25 persen mengalami gejala gangguan stres akut (mild-moderate) yang berpotensi berkembang ke arah gejala PTSD. Kembalinya pasien ke rumah juga tidak memberikan efek pengurangan gejala tersebut. Menurut penelitian yang dilakukan oleh Sun, dkk. (2020) dampak psikologis yang dialami pasien COVID-19 meliputi perasaan cemas, restlessness, helplessness, kemarahan, depresi, kesepian, ketakutan, insomnia, mimpi buruk, palpitasi, serta pusing-pusing. Gejala-gejala tersebut menggambarkan respon distres psikologis selama pandemi COVID-19.

Dampak lain yang dirasakan pasien yaitu adanya stigmatisasi, diskriminasi, serta pengabaian dari orang sekitar. Shaban, dkk. (2020) menyatakan dari hasil penelitian yang dilakukan bahwa saat menjalani perawatan di rumah sakit, awalnya pasien COVID-19 merasa cemas dan shock. Selanjutnya dampak tersebut berkembang menjadi perasaan takut (penularan ke orang lain dan stigmatisasi), merasa bersalah, kesepian, serta emosi negatif lainnya yang mengarah pada gejala depresi. Hal senada juga ditemukan dalam penelitian oleh Liu, dkk. (2020) yang mana ditemukan gejala depresi dan kecemasan

INSAN Jurnal Psikologi dan Kesehatan Mental

2021, Vol. 6(2), 106-116

doi: 10.20473/jpkm.v6i22021.106-116

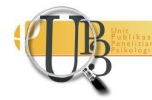


ringan pada hampir separuh sampel penelitian, sisanya mengalami gejala klinis yang signifikan terkait PTSD dan/atau depresi pada level sedang hingga berat. Hal ini juga dipengaruhi keluhan pasca keluarnya pasien dari rumah sakit serta adanya anggota keluarga yang terinfeksi COVID-19 dan meninggal dunia.

Adanya stigmatisasi dari orang sekitar dapat memperburuk dampak emosional. Sedangkan pada penelitian Cai, dkk. (2020) menunjukkan partisipan mengalami distres psikologis yang relatif intens yang meliputi stres berlebih, gejala kecemasan, serta gejala depresi yang muncul selama masa karantina. Faktor yang mempengaruhi distres psikologis pada penyintas COVID-19 meliputi usia, status pekerjaan, jenis kelamin, dukungan sosial, serta kehadiran anggota keluarga di sekitar partisipan. Gejala kecemasan dan depresi lebih umum ditemukan pada pasien COVID-19 dibandingkan pasien dengan penyakit lainnya. Faktor primer yang berhubungan dengan persepsi stres pasien yaitu ketidakpastian, adanya stigmatisasi, rasa kehilangan kontrol, dan ketidakberdayaan. Gejala PTSD yang dialami pasien berupa penghindaran terhadap pengalaman yang menimbulkan stres secara eksternal maupun internal, menyalahkan orang lain, serta perasaan negatif yang intens meliputi rasa takut, rasa bersalah, serta perasaan tidak berdaya (Guo, dkk., 2020).

\section{I S K U S I}

Berdasarkan paparan mengenai rincian artikel yang disintesis dalam studi ini, terdapat tiga gejala permasalahan psikologis utama yang dialami partisipan penelitian baik yang merupakan pasien COVID19 maupun yang non pasien, yaitu gejala kecemasan, gejala depresi, dan gejala PTSD. Bedasarkan hasil ulasan artikel yang telah disebutkan, adanya gejala kecemasan, depresi serta PTSD tersebut belum dapat dikatakan sebagai diagnosis klinis karena sebagian besar penelitian menggunakan instrumen pengambilan data berupa kuesioner mengenai gejala-gejala kecemasan, depresi, dan PTSD.

Gejala distres yang umumnya terjadi pada partisipan penelitian dari jurnal yang telah diulas meliputi gejala kecemasan, restlessness, helplessness, kemarahan, gejala depresi, gejala PTSD, kesepian, ketakutan, insomnia, mimpi buruk, palpitasi, serta pusing-pusing. Berdasarkan penjelasan dari American Psychiatric Association (APA) (2020), umumnya distres disebabkan oleh faktor eksternal dan biasanya bersifat jangka pendek, tergantung pada kehadiran stressor. Menurut Mirowsky dan Ross (2003), dua bentuk utama distres psikologis adalah gejala kecemasan dan gejala depresi. Gejala kecemasan yang dimaksud adalah kecenderungan perasaan sedang tegang, gelisah, khawatir, marah dan takut, sedangkan gejala depresi yang dimaksud meliputi perasaan sedih, kehilangan semangat, kesepian, putus asa atau tidak berharga, merasakan ingin mati, mengalami kesulitan tidur, menangis, merasa segala sesuatu adalah sebuah usaha, dan tidak mampu untuk pergi (Mirowsky \& Ross, 2003).

Gejala PTSD yang dialami berupa penghindaran terhadap pengalaman yang menimbulkan stres secara eksternal maupun internal, menyalahkan orang lain, serta perasaan negatif yang intens meliputi rasa takut, rasa bersalah, serta perasaan tidak berdaya. Menurut American Psychiatric Association (2013) salah satu onset dari PTSD adalah adalah peristiwa traumatis (stressful). Perasaan takut, cemas, dan penghindaran pada situasi yang menimbulkan trauma pada tingkat tertentu merupakan beberapa gejala dari PTSD (American Psychiatric Association, 2013).

\section{Distres Psikologis pada Masa Pandemi COVID-19}

Pada kelompok non-pasien COVID-19, individu dengan gangguan kecemasan dan gangguan mood memiliki ketakutan yang tinggi tehadap konsekuensi sosio-ekonomi, mengalami gejala PTSD yang tinggi dan lebih takut akan terkontaminasi COVID-19. Stressor yang ditemukan selama masa pandemi COVID19 yaitu karantina, hidup sendiri di masa pandemi, berada di kelompok yang berisiko tinggi tertular INSAN Jurnal Psikologi dan Kesehatan Mental 2021, Vol. 6(2), 106-116

doi: 10.20473/jpkm.v6i22021.106-116

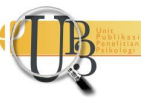


COVID-19, persepsi negatif mengenai kesehatan fisik orang sekitar, berada di dekat penderita COVID19, serta berada di dekat orang yang berisiko tinggi tertular COVID-19. Distres psikologis yang dialami yaitu gejala depresi, gejala kecemasan, insomnia, serta gejala stres akut. Pada kelompok pasien dan penyintas COVID-19 prevalensi kemunculan gejala depresi dan kecemasan tinggi. Beberapa mengalami gejala gangguan stres akut (mild-moderate) yang berpotensi berkembang ke arah gejala PTSD, serta ditemukan juga yang sudah menunjukkan gejala PTSD. Dampak psikologis lainnya yang dialami meliputi restlessness, helplessness, kemarahan, kesepian, ketakutan, mimpi buruk, palpitasi, serta pusing-pusing. Dampak lain yang dirasakan pasien dan penyintas COVID-19 yaitu adanya stigmatisasi, diskriminasi, serta pengabaian dari orang sekitar.

Sebagian besar partisipan keseluruhan penelitian yang dikaji dalam tulisan ini mengalami setidaknya satu gejala yang mengarah pada kecemasan, depresi, dan stres akut, serta beberapa partisipan mengalami gejala yang mengarah pada PTSD (Cai, dkk., 2020; Guo, dkk., 2020; Liu, dkk., 2020; Parker, dkk., 2020). Gejala yang ditemukan terkait depresi dan kecemasan tersebut berpotensi mengalami peningkatan akibat faktor tertentu yang dibawa individu maupun adanya faktor eksternal. Selain itu, gejala stres akut juga sering ditemukan pada individu pada masa pandemi COVID-19. Pada beberapa penelitian ditemukan bahwa gejala distres tersebut telah berkembang ke arah PTSD. Pasien yang telah sembuh dan diizinkan pulang ke rumah cenderung mengalami penurunan gejala kecemasan, namun gejala depresi dan stres akut secara umum dirasakan relatif persisten (Parker, dkk., 2020). Studi terkini menjelaskan bahwa keterbatasan fisik dapat memicu kemunculan masalah psikologis. Hal ini berhubungan dengan aspek biologis dari kemunculan distres akibat kurangnya latihan kebugaran fisik (Shah, Mohammad, Qureshi, Abbas, \& Aleem, 2021).

\section{Stressor pada Masa Pandemi COVID-19}

Adapun hal-hal yang menjadi stressor bagi populasi terdampak COVID-19 yaitu adanya keluarga yang tertular atau meninggal karena COVID-19, kondisi tidak pasti yang dihadapi sehingga kontrol terhadap hal-hal yang mungkin terjadi juga merosot, ketidakberdayaan dalam menghadapi segala batasan yang harus ditaati selama menjalani karantina, serta persepsi negatif mengenai kondisi kesehatan orang lain. Tidak semua individu mampu mentaati protokol kesehatan yang diberlakukan pemerintah, sehingga hal ini menjadi tekanan tersendiri bagi orang lain yang berada di sekitar individu tersebut.

Tinggal sendirian tanpa keluarga juga dapat memperparah kesepian yang dialami individu selama menjalani karantina, sehingga menimbulkan kurangnya dukungan sosial. Selain itu menjadi bagian dari kelompok yang berisiko tinggi, berada di sekitar orang yang berisiko tinggi, serta berada di dekat penderita COVID-19 juga membuat individu merasa harus ekstra hati-hati, sehingga hal ini berpotensi menimbulkan distres bagi individu tersebut. Salah satu stressor yang dominan dirasakan individu terdampak COVID-19 yaitu adanya stigmatisasi dan diskriminasi (Guo, dkk., 2020; Liu, dkk., 2020; Shaban, dkk., 2020; Sun, dkk., 2020). Hal ini senada dengan penelitian oleh Ramaci, dkk (2020) yang menjelaskan bahwa orang-orang yang terinfeksi COVID-19 dicurigai dan distigmatisasi sehingga timbul diskriminasi yang hanya akan menambah penderitaan mereka secara psikologis. 
Tabel 1. Rangkuman Jenis Stressor dan Distres Psikologis pada Masa Pandemi COVID-19

\begin{tabular}{ll}
\hline \multicolumn{1}{c}{ Jenis Stressor } & \multicolumn{1}{c}{ Distres Psikologis } \\
\hline $\begin{array}{l}\text { Adanya keluarga yang tertular atau } \\
\text { meninggal karena COVID-19 }\end{array}$ & $\begin{array}{l}\text { Gejala kecemasan, gejala depresi, gejala } \\
\text { stres akut, gejala PTSD, restlessness, } \\
\text { helplessness, kemarahan, kesepian, } \\
\text { ketakutan, merasa bersalah, rasa } \\
\text { kehilangan kontrol, ketidakpastian }\end{array}$ \\
$\begin{array}{ll}\text { Kondisi tidak pasti yang dihadapi sehingga } \\
\text { kontrol terhadap hal-hal yang mungkin } \\
\text { terjadi juga merosot }\end{array}$ & $\begin{array}{l}\text { Insomnia, mimpi buruk, pusing-pusing dan } \\
\text { palpitasi }\end{array}$ \\
$\begin{array}{l}\text { Ketidakberdayaan dalam menghadapi } \\
\text { segala batasan yang harus ditaati selama } \\
\text { menjalani karantina }\end{array}$ & $\begin{array}{l}\text { Penghindaran terhadap pengalaman yang } \\
\text { menimbulkan stres secara eksternal } \\
\text { maupun internal dan menyalahkan orang }\end{array}$ \\
$\begin{array}{l}\text { Persepsi negatif mengenai kondisi } \\
\text { kesehatan orang lain } \\
\text { Tidak semua individu mampu mentaati } \\
\text { protokol kesehatan yang diberlakukan } \\
\text { pemerintah }\end{array}$ & \\
$\begin{array}{l}\text { Tinggal sendirian tanpa keluarga } \\
\text { Menjadi bagian dari kelompok yang } \\
\text { berisiko tinggi }\end{array}$ & \\
Stigmatisasi dan diskriminasi \\
Pengabaian dari orang sekitar
\end{tabular}

\section{S I M P U L A N}

Bentuk distres psikologis yang kerap ditemukan pada masa pandemi COVID-19 yaitu gejala kecemasan, gejala depresi, gejala stres akut, dan gejala PTSD. Gejala stres akut yang dialami individu berisiko berkembang ke arah PTSD. Dampak psikologis lainnya berupa perasaan kesepian, ketidakberdayaan, kemarahan, takut akan penularan pada orang lain serta takut akan adanya stigmatisasi, insomnia, penghindaran stressor, mimpi buruk, pusing, serta palpitasi.

Penyebab kemunculan gejala-gejala tersebut dipicu oleh adanya stressor berupa kondisi di masa pandemi yang serba tidak pasti, hilangnya sense of control, ketidakberdayaan, persepsi negatif terkait kesehatan orang lain, tinggal sendirian saat menjalani karantina, tingginya risiko individu terpapar COVID-19, dekatnya jarak dengan orang yang berisiko tinggi atau penderita COVID-19, serta adanya stigmatisasi dari orang sekitar. Dengan mengenali gejala distres psikologis serta stressor apa saja yang mungkin memicunya, masyarakat diharapkan lebih waspada jika gejala-gejala tersebut mulai menghambat fungsi sosial dan kegiatan sehari-hari. Hal ini bertujuan sebagai tindakan preventif terhadap kemunculan gangguan psikologis. Apabila gejala yang dirasakan sudah pada tahap menghambat kegiatan sehari-hari, maka diperlukan bantuan profesional seperti psikolog dan psikiater. 


\section{DEKLARASI POTENSI TERJADINYAKONFLIK KEPENTINGAN}

Gusti Ayu Ardhia Candra Trikusuma tidak bekerja, menjadi konsultan, memiliki saham, atau menerima dana dari perusahaan atau organisasi manapun yang mungkin akan mengambil untung dari diterbitkannya naskah ini.

\section{PUS TAKA ACUAN}

American Psychiatric Association. (2013). Diagnostic and Statistical Manual of Mental Disorders DSM-5 (5 ${ }^{\text {th }}$ Edition). London: American Psychiatric Publishing.

Asmundson, G. J., Paluszek, M. M., Landry, C. A., Rachor, G. S., McKay, D., \& Taylor, S. (2020). Do preexisting anxiety-related and mood disorders differentially impact COVID-19 stress responses and coping?. Journal of anxiety disorders, 74, 102271. https://doi.org/10.1016/j.janxdis.2020.102271

Cai, X., Hu, X., Ekumi, I. O., Wang, J., An, Y., Li, Z., \& Yuan, B. (2020). Psychological distress and its correlates among COVID-19 survivors during early convalescence across age groups. The American Journal of Geriatric Psychiatry, 28(10), 1030-1039. https://doi.org/10.1016/i.jagp.2020.07.003

Centers for Disease Control and Prevention (CDC). (2020). Pandemics Can Be Stressful. Diakses dari https://www.cdc.gov/coronavirus/2019-ncov/daily-life-coping/managing-stress-anxiety.html

Dong, L., \& Bouey, J. (2020). Public mental health crisis during COVID-19 pandemic, China. Emerging infectious diseases, 26(7), 1616. https://doi.org/10.3201/eid2607.200407

Folkman, S., \& Lazarus, R. S. (1985). If it changes it must be a process: study of emotion and coping during three stages of a college examination. Journal of personality and social psychology, 48(1), 150. https://doi.org/10.1037/0022-3514.48.1.150

Gadzella, B. M., Baloglu, M., Masten, W. G., \& Wang, Q. (2012). Evaluation of the Student Life-stress Inventory-Revised. Journal of Instructional Psychology, 39(2).

Guo, Q., Zheng, Y., Shi, J., Wang, J., Li, G., Li, C., ... \& Yang, Z. (2020). Immediate psychological distress in quarantined patients with COVID-19 and its association with peripheral inflammation: a mixedmethod study. Brain, behavior, and immunity, 88, 17-27. https://doi.org/10.1016/j.bbi.2020.05.038

Katona, C., Cooper, C., \& Robertson, M. (2012). At Glance Psikiatri: Edisi Keempat. Jakarta: Erlangga.

Lahav, Y. (2020). Psychological distress related to COVID-19-the contribution of continuous traumatic stress. Journal of affective disorders, 277, 129-137. https://doi.org/10.1016/i.jad.2020.07.141

Liu, D., Baumeister, R. F., Veilleux, J. C., Chen, C., Liu, W., Yue, Y., \& Zhang, S. (2020). Risk factors associated with mental illness in hospital discharged patients infected with COVID-19 in Wuhan, China. Psychiatry Research, 292, 113297. https://doi.org/10.1016/j.psychres.2020.113297

Mashabi, S. (2020). 6 Bulan Pandemi Covid-19: Catatan tentang PSBB dan Penerapan Protokol Kesehatan. Diakses dari https://nasional.kompas.com/read/2020/09/03/09002161/6-bulanpandemi-covid-19-catatan-tentang-psbb-dan-penerapan-protokol?page=all

Mirowsky, J., \& Ross, C. E. (2003). Social Causes of Psychological Distress. New York: Aldine De Gruyter.

Parker, C., Shalev, D., Hsu, I., Shenoy, A., Cheung, S., Nash, S., ... \& Shapiro, P. A. (2021). Depression, Anxiety, and Acute Stress Disorder Among Patients Hospitalized With COVID-19: A Prospective

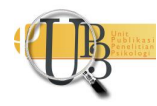


Cohort Study. Journal of the Academy of Consultation-Liaison Psychiatry, 62(2), 211-219. https://doi.org/10.1016/j.psym.2020.10.001

Perhimpunan Dokter Spesialis Kesehatan Jiwa Indonesia. (2020). 5 bulan pandemi COVID-19 di Indonesia. Diakses dari http://pdskji.org/home

Ramaci, T., Barattucci, M., Ledda, C., \& Rapisarda, V. (2020). Social stigma during COVID-19 and its impact on HCWs outcomes. Sustainability, 12(9), 3834. https://doi.org/10.3390/su12093834

Sarafino, E. P., \& Smith, T. W. (2014). Health psychology: Biopsychosocial interactions (8 ${ }^{\text {th }}$ Edition). New Jersey: John Wiley \& Sons.

Shaban, R. Z., Nahidi, S., Sotomayor-Castillo, C., Li, C., Gilroy, N., O'Sullivan, M. V., ... \& Bag, S. (2020). SARS-CoV-2 infection and COVID-19: The lived experience and perceptions of patients in isolation and care in an Australian healthcare setting. American Journal of Infection Control, 48(12), 14451450. https://doi.org/10.1016/j.ajic.2020.08.032

Shah, S. M. A., Mohammad, D., Qureshi, M. F. H., Abbas, M. Z., \& Aleem, S. (2021). Prevalence, Psychological Responses and associated correlates of depression, anxiety and stress in a global population, during the coronavirus disease (COVID-19) pandemic. Community mental health journal, 57(1), 101-110. https://doi.org/10.1007/s10597-020-00728-y

Shi, L., Lu, Z. A., Que, J. Y., Huang, X. L., Liu, L., Ran, M. S., ... \& Lu, L. (2020). Prevalence of and risk factors associated with mental health symptoms among the general population in China during the coronavirus disease 2019 pandemic. JAMA network open, 3(7), e2014053-e2014053. https://doi.org/10.1001/jamanetworkopen.2020.14053

Sun, N., Wei, L., Shi, S., Jiao, D., Song, R., Ma, L., ... \& Wang, H. (2020). A qualitative study on the psychological experience of caregivers of COVID-19 patients. American journal of infection control, 48(6), 592-598. https://doi.org/10.1016/j.ajic.2020.03.018

Taylor, S. (2019). The Psychology of Pandemic. UK: Cambridge Scholars Publishing.

Thakur, V., \& Jain, A. (2020). COVID 2019-suicides: A global psychological pandemic. Brain, behavior, and immunity, 88, 952. https://doi.org/10.1016/j.bbi.2020.04.062

World Health Organization (WHO). (2020). Mental Health and COVID-19. Diakses dari https://www.euro.who.int/en/health-topics/health-emergencies/coronavirus-covid19/publications-and-technical-guidance/noncommunicable-diseases/mental-health-and-covid-19 